\title{
Host Specificity and Tomato-Related Race Composition of Phytophthora infestans Isolates in Taiwan During 2004 and 2005
}

\author{
Chien-Hua Chen, Zong-Ming Sheu, and Tien-Cheng Wang, Asian Vegetable Research and Development Center- \\ The World Vegetable Center, Shanhua, Tainan, 74199 Taiwan ROC
}

\begin{abstract}
Chen, C.-H., Sheu, Z.-M., and Wang, T.-C. 2008. Host specificity and tomato-related race composition of Phytophthora infestans isolates in Taiwan during 2004 and 2005. Plant Dis. 92:751755.

Late blight, caused by Phytophthora infestans, is a major disease of tomato in cool and wet environments. In this study, we report on the host specificity, race composition, and variation among races revealed by amplified fragment length polymorphism (AFLP) of $P$. infestans isolated from tomato production areas in Taiwan. In all, 177 P. infestans isolates were collected in Taiwan during 2004 and 2005. All were aggressive on both potato and tomato. Nine physiological races were identified based on disease response on a set of tomato differentials developed by the Asian Vegetable Research and Development Center-The World Vegetable Center. Eighty-seven polymorphic bands from 32 isolates of four races were detected by AFLP. No significant correlation between the polymorphism and the races was found using cluster analysis. This study revealed that a high variability of race composition among the asexual population of $P$. infestans isolates existed in Taiwan during 2004 and 2005. Breeding new tomato cultivars for resistance to P. infestans is an urgent and ongoing need because new races of the pathogen appeared continuously in Taiwan in past years. Further analysis of the genomic diversity is necessary to determine whether the high genetic variation of $P$. infestans is related to the complex race composition.
\end{abstract}

Additional keywords: differential hosts, pathogenicity

Late blight, caused by Phytophthora infestans (Mont.) de Bary, is a destructive disease of tomato and potato worldwide, especially during cool and moist weather conditions. Disease outbreaks have increased in frequency and severity during the last two decades and this has been associated with the migration of new and more aggressive strains of the pathogen $(17,18,34)$. Since 1998, severe late blight epidemics have occurred on both tomato and potato crops in Taiwan concomitant with the appearance of a new pathogen population $(3,24)$.

There are apparent differences between the original and the new populations based on metalaxyl sensitivity, allozyme genotype, mitochondrial DNA (mtDNA) haplotype, and restriction fragment length polymorphism (RFLP) fingerprinting $(3,6,13,24)$. The new population was characterized as metalaxyl resistant, IIb mtDNA haplotype, and the dilocus allozyme genotype 100/100/111 and 100/100 for the loci coding for glucose-6-phosphate isomerase $(\mathrm{Gpi})$ and peptidase (Pep), re-

Corresponding author: T.-C. Wang

E-mail: tcwang@netra.avrdc.org.tw

Accepted for publication 2 January 2008.

doi:10.1094/PDIS-92-5-0751

(C) 2008 The American Phytopathological Society spectively. These characters, together with RG57 fingerprinting, indicated that these isolates belonged to the US-11 clonal lineage, whereas the original isolates belonged to the US-1 clonal lineage which is metalaxyl sensitive, Ib mtDNA haplotype, and the allozyme genotype $86 / 100$ and 92/100 (100/100) for Gpi and Pep, respectively, as well as the unique fingerprinting pattern $(3,6,13,24)$. The US- 1 and the US11 genotypes of $P$. infestans differ in host specificity as well as neutral genetic markers. (4).

It is highly plausible that the new genotype was introduced to Taiwan in imported table potato during the 1997-98 growing season (13). By 2000, the new genotype had completely displaced the US- 1 genotype that had been collected in Taiwan before $1997(6,13)$.

Three race-specific late blight resistance genes, $P h-1, P h-2$, and $P h-3$, have been introgressed into tomato from different accessions of Solanum pimpinellifolium in past years. $P h-3$, a partially dominant allele derived from the L3708 accession ( $S$. pimpinellifolium), has been incorporated into Asian Vegetable Research and Development Center (AVRDC) lines with the prefix CLN2037. Subsequent research has demonstrated that L3708 carries at least one other late blight resistance gene in addition to $P h-3(7,25)$. LA1033, an $S$. hobrochaites accession (formerly Lycopersicon hirsutum), has shown a different spectrum of resistance to $P$. infestans compared with L3708, and inheritance studies have suggested that LA1033 contains at least two late blight resistance genes (28).

The virulence of the $P$. infestans population within the single US-11 lineage collected in Taiwan is complex and variable $(7,8)$. Genetic markers such as allozymes, mtDNA haplotype, and RG57 fingerprinting have not been found to correspond to virulence factors. Amplified fragment length polymorphism (AFLP) is a stable and reliable technique for analysis of variations at the DNA level (37). The genetic markers of $P$. infestans isolated from potato and analyzed by AFLP strategies were reported in recent years $(35,36)$; however, there are fewer reports on $P$. infestans isolated from tomato.

The objectives of this study were to (i) characterize the host specificity of $P$. infestans isolates collected during 2004 and 2005 in Taiwan, (ii) identify the race composition within the same population through a set of tomato differentials, and (iii) examine variation among these isolates at the DNA level using AFLP.

\section{MATERIALS AND METHODS}

Isolates. Isolates of $P$. infestans were obtained from infected leaf, stem, or fruit tissues of tomato plants in Taiwan during 2004 and 2005. Each diseased sample was collected from a single field. In total, 177 isolates were collected from commercial fields, home gardens, and research plots in 14 counties around Taiwan during the tomato growing season in the highlands and the lowlands in summer and winter, respectively (Fig. 1).

Isolation and maintenance of the pathogen. Infected host tissue without sporulation was placed in a petri dish with a piece of moistened filter paper at $20^{\circ} \mathrm{C}$ for 1 to 4 days to induce sufficient sporulation for the isolation. Isolates were obtained by transferring fresh sporangia to antibioticamended rye A agar plates amended with ampicillin (100 mg/liter), nyststin (100 $\mathrm{mg} /$ liter), and rifamipicin (50 mg/liter) (9) using a small agar block on the tip of a spatula (14). The cultures were grown on rye A agar plates after isolation. Subsequently, the isolates were maintained in rye A agar slants filled with mineral oil and in test tubes filled with autoclaved rye grain and distilled water incubated at 16 to $20^{\circ} \mathrm{C}$.

Host specificity. Isolates were inoculated on tomato and potato to test the host 
specificity. Inoculum was made by harvesting sporangia from colonies grown on rye A agar plates; sporangial suspensions were quantified using a hemacytometer, adjusted to a concentration of $5 \times 10^{4}$ sporangia $/ \mathrm{ml}$, then incubated at $12^{\circ} \mathrm{C}$ for $3 \mathrm{~h}$ to induce the release of zoospores. The zoospore/sporangia suspensions of each isolate was atomized on six tomato seedlings at 35 days after sowing (AVRDC accession CL5915, S. lycopersicum) and on six potato seedlings at 49 days after sowing (Kennebec, S. tuberosum Lour.) in each of three replications. Tomato accession CL5915 and potato cv. Kennebec do not contain any $P h$ or $R$ gene resistance to late blight, respectively. Plants atomized with water were used as controls. The inoculated seedlings were incubated at $100 \%$ relative humidity $(\mathrm{RH})$ and $20 \pm 2{ }^{\circ} \mathrm{C}$ without light in the growth room for the first $24 \mathrm{~h}$. Thereafter, the conditions were adjusted to 60 to $95 \% \mathrm{RH}$ and $20 \pm 2{ }^{\circ} \mathrm{C}$ with a 14-h light $\left(70 \mu \mathrm{E} \mathrm{m}^{-2} \mathrm{~s}^{-1}\right)$ period per day. The pathogenicity of each isolate on tomato was evaluated at 10 days after inoculation by visually scoring disease severity using a scale of 0 to 6 , where 0 indicated no symptoms; 1 indicated 1 to $5 \%$ leaf area affected, small leaf lesions $(<2$ $\mathrm{mm}$ ), and no stem lesion; 2 indicated 6 to $15 \%$ leaf area affected, necrosis-restricted leaf lesions, and no stem lesion; 3 indicated 16 to $30 \%$ leaf area affected, coalescent leaf lesions, or tiny water-soaked stem lesions; 4 indicated 31 to $60 \%$ of leaf area affected, edge-expanding leaf lesions, or a few small stem lesions $(<5 \mathrm{~mm}) ; 5$ indicated 61 to $90 \%$ of leaf area affected, drying leaf lesions, or edge-expanding stem lesions; and 6 indicated 91 to $100 \%$ of leaf area affected, leaves blighting, extensive stem damage, or plant dead (5).

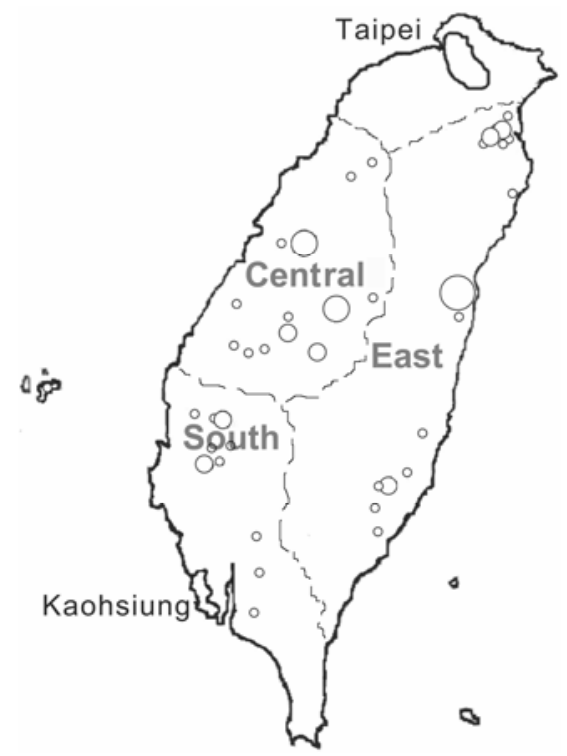

Fig. 1. Locations of Phytophthora infestans isolates collected in Taiwan during 2004 and 2005. Circle size corresponds to the number of infected samples collected.
Determination of physiological race. The zoospore/sporangia suspensions $(5 \times$ $10^{4} / \mathrm{ml}$ ) of all isolates were atomized on six tomato differentials at 35 days after sowing. Putative genotypes of tomato differentials are TS19 $\left(P h^{+}\right)$, TS33 $(P h-1), \mathrm{W}$. Va. $700(P h-2)$, CLN2037B $(P h-3)$, L3708 $(P h-3,4(?))$, and LA1033 $(P h-5(?))$. The symbols $P h-4$ and $P h-5$ are tentative. The conditions for inoculation and incubation were as described above, and six plants in each of three replications were inoculated. The disease severity of each plant was evaluated as mentioned above. Based on the mean disease severity rating from six inoculated plants, the sensitivity of the differential hosts to each $P$. infestans isolate could be determined. A mean disease severity rating of 3.5 or greater on a differential was evaluated as a defeated resistance gene. The race designation is derived from the resistance genes that are defeated by the isolate; for instance, tomato race T1,2 will overcome the resistance of TS33 and W. Va. 700, which possess the $P h-1$ and $P h-2$ genes, respectively.

DNA isolation and AFLP DNA fingerprinting. Based on the identification of the phenotypic reactions, four tomato races (T1; $\mathrm{T} 1,2 ; \mathrm{T} 1,3$; and $\mathrm{T} 1,2,3,5)$ from 32 isolates were selected for AFLP fingerprinting analysis. The isolates were cultured in pea broth at $20^{\circ} \mathrm{C}$ for 2 weeks for DNA extraction (13). DNA isolation was conducted with a commercial DNA extraction kit (Viogene Co., Cat. GPG1001).

AFLP DNA fingerprinting was modified from the protocol developed by Vos et al. (37), which allowed the detection of AFLP bands with fluorescence-labeled nucleotides. Template DNA was prepared by the restriction-ligation reaction, which digests genomic DNA with restriction enzymes EcoRI, MseI, and SacI, then ligates with adapters fitting the restriction sites of each restriction enzyme. The sequence of the adapter fitting the EcoRI site was 5'CTCGTAGACTGCGTACC-3' and $3^{\prime}$-CTG ACGCATGGTTAA-5'. The sequence of the adapter fitting the $\mathrm{Mse}$ I site was $5^{\prime}$ GACGATGAGTCCTGAG-3' and 3'-CTA CTCAGGACTCATT-5'. The sequence of the adapter site fitting the SacI site was 5'CTCGTAGACTGCGTACAAGCT- $3^{\prime}$ and 3'-CATCTGACGCATGTTCGAG-5'.

Template DNA then was preamplified by primers to reduce the complexity of the template fragments and to increase quantities of the target templates for selective amplification with fluorescence-labeled primers. The primers used in the preamplification corresponded to the adapter ends of the templates accompanied with one selective nucleotide, so-called $\mathrm{E}+1, \mathrm{M}+1$, and $\mathrm{S}+1$ primers, where $\mathrm{E}, \mathrm{M}$, and $\mathrm{S}$ stand for EcoRI, MseI, and SacI, respectively. The sequence of the primers were as follows: E+1, 5'-GACTGCGTACCAATTCA$3^{\prime}(\mathrm{E}+\mathrm{A})$ and 5'-GACTGCGTACCA ATTCC-3' (E+C); M+1, 5'-GATGAGTCC TGAGTAAA-3' $(\mathrm{M}+\mathrm{A})$ and $5^{\prime}-\mathrm{GATGAG}$ TCCTGAGTAAC-3' $(\mathrm{M}+\mathrm{C})$; and $\mathrm{S}+1,5^{\prime}-$ GTAGACTGCGTACAAGCTCA-3' (S+A) and 5'-GTAGACTGCGTACAAGCTCC-3' $(\mathrm{S}+\mathrm{C})$, in which $\mathbf{A}$ and $\mathbf{C}$ are the selective nucleotides. The primer combinations were $(\mathrm{E}+1)$ and $(\mathrm{M}+1)$ or $(\mathrm{S}+1)$ and $(\mathrm{M}+1)$, and preamplification was performed in a $25-\mu \mathrm{l}$ reaction volume using the autorisierter thermal cycler (Eppendorf, Mastercycler gradient), programmed for 34 cycles of $94^{\circ} \mathrm{C}$ for $30 \mathrm{~s}, 56^{\circ} \mathrm{C}$ for $30 \mathrm{~s}$, and $72^{\circ} \mathrm{C}$ for $90 \mathrm{~s}$. The polymerase chain reaction $(\mathrm{PCR})$ reaction contained $160 \mu \mathrm{M}$ dNTPs mix, $1 \times$ PCR buffer with 4 $\mathrm{mM} \mathrm{MgCl}_{2}, 0.4$ unit of Taq DNA polymerase, $0.2 \mu \mathrm{M}$ each preamplified primer, and $160 \mathrm{ng}$ of digested DNA.

The products of preamplification were used as the DNA templates for the selec-

Table 1. Primer combinations used for amplified fragment length polymorphism analysis of Phytophthora infestans isolates

\begin{tabular}{|c|c|c|c|}
\hline $\begin{array}{l}\text { Preamplified primer } \\
\text { combination }^{\mathrm{a}}\end{array}$ & $\begin{array}{c}\text { Selective amplified } \\
\text { primer combination }^{b}\end{array}$ & $\begin{array}{l}\text { Total number of } \\
\text { bands amplified }\end{array}$ & $\begin{array}{c}\text { Number of } \\
\text { polymorphic bands }\end{array}$ \\
\hline E-A+M-A & E-C+M-ATAT & 73 & 5 \\
\hline E-A+M-C & E-C+M-ATAT & 69 & 7 \\
\hline E-A+M-A & E-AA+M-CTT & 64 & 5 \\
\hline E-A+M-A & E-AA+M-AATT & 68 & 4 \\
\hline E-A+M-A & E-AA+M-ATAT & 78 & 5 \\
\hline $\mathrm{E}-\mathrm{A}+\mathrm{M}-\mathrm{C}$ & E-AC+M-CCGG & 62 & 2 \\
\hline $\mathrm{E}-\mathrm{C}+\mathrm{M}-\mathrm{A}$ & $\mathrm{E}-\mathrm{AC}+\mathrm{M}-\mathrm{CCGG}$ & 88 & 12 \\
\hline $\mathrm{S}-\mathrm{A}+\mathrm{M}-\mathrm{A}$ & S-C+M-ATAT & 73 & 8 \\
\hline S-A+M-C & S-C+M-AATT & 71 & 4 \\
\hline $\mathrm{S}-\mathrm{C}+\mathrm{M}-\mathrm{A}$ & S-C+M-ATAT & 78 & 12 \\
\hline S-A+M-A & S-AC+M-CTA & 60 & 6 \\
\hline $\mathrm{S}-\mathrm{C}+\mathrm{M}-\mathrm{C}$ & $\mathrm{S}-\mathrm{AA}+\mathrm{M}-\mathrm{CAA}$ & 65 & 3 \\
\hline $\mathrm{S}-\mathrm{C}+\mathrm{M}-\mathrm{C}$ & S-AA+M-CTT & 77 & 4 \\
\hline S-C+M-A & S-AA+M-ATAT & 63 & 7 \\
\hline $\mathrm{S}-\mathrm{C}+\mathrm{M}-\mathrm{A}$ & S-AC+M-CGCG & 68 & 3 \\
\hline Total & $\ldots$ & 1,057 & 87 \\
\hline
\end{tabular}

a Primers complementary to the adaptors. The sequence of primer E was 5'-GACTGCGTACCAATTC-3',

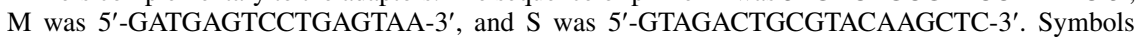
followed by a dash mean that selective nucleotides were attached to the $3^{\prime}$ end of the primers.

${ }^{b}$ The IRDye700 is labeled on the $3^{\prime}$ end of the Sac-attached nucleotide primers, and the IRDye800 is labeled on the $3^{\prime}$ end of the Eco-attached nucleotide primers. 
tive PCR amplification. The secondary templates were amplified by primers containing one to four selective nucleotides with a fluorescence-label at the $3^{\prime}$ end. Selective amplification was carried out with 15 primer-pair combinations (Table 1). Fluorescence dye IRDye 700 was used to label the $\mathrm{S}$ primers and IRDye 800 was used to label the E primers.

The amplification reaction was performed in $20 \mu \mathrm{l}$ of the reaction volume, containing $1 \times$ reaction buffer with $2.5 \mathrm{mM}$ $\mathrm{MgCl}_{2}, 200 \mu \mathrm{M}$ dNTPs mix, 0.5 unit of Taq DNA polymerase, $0.2 \mu \mathrm{M} \mathrm{E}$ and $\mathrm{S}$ primers, $0.4 \mu \mathrm{M} \mathrm{M}$ primer, and $5 \mu \mathrm{l}$ of a 20-fold dilution of the preamplified DNA template. The PCR reaction started with a cycle of $30 \mathrm{~s}$ at $94^{\circ} \mathrm{C}, 30 \mathrm{~s}$ at $65^{\circ} \mathrm{C}$, and 1 min at $72^{\circ} \mathrm{C}$, and was followed by $12 \mathrm{cy}-$ cles with a stepwise lowering of the annealing temperature by $0.7^{\circ} \mathrm{C}$ in each cycle, followed by 23 cycles of $94^{\circ} \mathrm{C}$ for 30 $\mathrm{s}, 56^{\circ} \mathrm{C}$ for $30 \mathrm{~s}$, and $72^{\circ} \mathrm{C}$ for $90 \mathrm{~s}$.

The selectively amplified PCR products were separated in a denaturing polyacrylamide gel. Gels were read by a DNA sequencer ( $\mathrm{Li}$-COR LONG READIR 4200/4300), which detects fluorescence signals automatically.

AFLP data analysis. The AFLP bands were scored manually and analyzed as binary data, with 1 representing the presence and 0 representing the absence of a band at a particular location in each lane. Polymorphic bands were assumed to be independent, and those of identical size were assumed to have identical sequences. Data were analyzed with the computer software NTSYS-pc version 2.1. Similarity matrices were obtained based on the simple matching coefficients, using the SIMQUAL program in the software package. Cluster analysis of matrix values was performed by the unweighted pair-group method with arithmetic averages using the SHAN algorithm of NTSYS-pc (33). Dendrograms showing the relationships among the AFLP patterns were generated from the matrices using the TREE program from NTSYS-pc.

\section{RESULTS}

Host specificity. All isolates exhibited high virulence and showed severe symptoms (disease rating of 6) on tomato and potato after artificial inoculation. There was no host specificity to tomato or potato within the $P$. infestans populations collected from tomato in Taiwan.

Determination of physiological race. The virulence patterns of Taiwan $P$. infestans populations were highly diverse, as shown by reactions of the differentials. In all, 177 isolates were grouped into nine physiological races consisting of race $\mathrm{T} 1$; $\mathrm{T} 1,2 ; \quad \mathrm{T} 1,3 ; \quad \mathrm{T} 1,2,3 ; \quad \mathrm{T} 1,3,5 ; \quad \mathrm{T} 1,2,3,4 ;$ $\mathrm{T} 1,2,3,5 ; \mathrm{T} 1,3,4,5$; and $\mathrm{T} 1,2,3,4,5$ (Table 2). Race $\mathrm{T} 1,2,3$, was the predominant race in South and East Taiwan (Table 3). However, races $\mathrm{T} 1,2 ; \mathrm{T} 1,2,3$; and $\mathrm{T} 1,2,3,4$ were equally common in Central Taiwan (Table 3).

AFLP DNA fingerprinting. All 15 primer pairs successfully amplified DNA from the $32 P$. infestans isolates. For each primer pair, 71 to 126 DNA fragments ranging from 50 to $800 \mathrm{bp}$ were detected. In all, 1,057 amplification products were detected, of which 87 markers $(8.23 \%)$ were polymorphic (Table 1). None of the primer pairs screened showed the ability to distinguish all 32 isolates as distinct AFLP genotypes. When the polymorphisms were compared, the majority of the bands were common to all isolates, whereas others were unique to one or a few isolates, as exemplified by the primer pair E-AA-MATAT (Fig. 2).

Values of similarity coefficients of the AFLP data ranged from 0.63 to 0.95 . Hierarchical clustering at the $80 \%$ similarity level separated the $32 P$. infestans isolates into five AFLP groups (AFGs). The majority of the isolates clustered in AFG1 (22 isolates). Six isolates clustered in AFG3. AFG2 contained two isolates, Pi364 and Pi399. Isolates Pi363 and Pi391 formed separate clusters, AFG4 and AFG5, respectively (Fig. 3).

\section{DISCUSSION}

The primary objective of this research was to characterize isolates collected from tomato in Taiwan during 2004 and 2005 in terms of host specificity, race, and variation at the DNA level revealed by AFLP. All isolates were characterized as the US11 genotype (data not show) and were aggressive to both tomato and potato by artificial inoculation. There was no host specificity on tomato or potato among the $P$. infestans isolates tested.

Table 3. Distribution of the physiological races among the sampling locations ${ }^{\mathrm{a}}$

\begin{tabular}{lcccc}
\hline Race $^{\mathbf{b}}$ & Central Taiwan & South Taiwan & East Taiwan & No. of isolates \\
\hline T1 & 6 & 3 & 9 & 18 \\
T1,2 & $14^{\mathrm{c}}$ & 1 & 9 & 24 \\
$\mathrm{~T} 1,3$ & 3 & 4 & 7 & 14 \\
$\mathrm{~T} 1,2,3$ & 13 & 28 & 33 & 74 \\
$\mathrm{~T} 1,3,5$ & 1 & 1 & 1 & 3 \\
$\mathrm{~T} 1,2,3,4$ & 10 & 0 & 7 & 17 \\
$\mathrm{~T} 1,2,3,5$ & 4 & 6 & 8 & 18 \\
T1,3,4,5 & 0 & 0 & 1 & 1 \\
T1,2,3,4,5 & 3 & 4 & 1 & 8 \\
Total & 54 & 47 & 76 & 177 \\
\hline
\end{tabular}

a Location collected: Central Taiwan includes Miaoli, Taichung, Nantou, and Changhua counties; South Taiwan includes Yunlin, Chiayi, Tainan, Ponhu, Kaohsiung, and Pingtung counties; and East Taiwan includes Ilan, Hualien, and Taitung counties.

${ }^{b}$ Race designation is derived from the resistance genes that are defeated by the isolate; for instance, race T1,2 overcomes the resistance of TS33 and WV700, which possess the $P h-1$ and $P h-2$ genes, respectively.

${ }^{c}$ One isolate was collected from Hsinchu county in North Taiwan.

Table 2. Designation of putative physiological races of Phytophthora infestans isolates collected from tomato in Taiwan during 2004 and 2005

\begin{tabular}{|c|c|c|c|c|c|c|c|}
\hline \multirow[b]{2}{*}{ Race $^{b}$} & \multicolumn{6}{|c|}{ Differential hosts (genes) $^{a}$} & \multirow[b]{2}{*}{ No. of isolates } \\
\hline & TS19 $(P h+)$ & TS33 (Ph-1) & W. Va. $700(P h-2)$ & CLN2037B $(P h-3)^{\mathrm{c}}$ & L3708 $(P h-3,4)$ & LA1033 $(P h-5)$ & \\
\hline $\mathrm{T} 1$ & $\mathrm{~S}$ & $\mathrm{~S}$ & $\mathrm{R}$ & $\mathrm{R}$ & $\mathrm{R}$ & $\mathrm{R}$ & 18 \\
\hline $\mathrm{T} 1,2$ & $\mathrm{~S}$ & $\mathrm{~S}$ & $\mathrm{~S}$ & $\mathrm{R}$ & $\mathrm{R}$ & $\mathrm{R}$ & 24 \\
\hline $\mathrm{T} 1,3$ & $\mathrm{~S}$ & $\mathrm{~S}$ & $\mathrm{R}$ & $\mathrm{S}$ & $\mathrm{R}$ & $\mathrm{R}$ & 14 \\
\hline $\mathrm{T} 1,2,3$ & $\mathrm{~S}$ & $\mathrm{~S}$ & $\mathrm{~S}$ & $\mathrm{~S}$ & $\mathrm{R}$ & $\mathrm{R}$ & 74 \\
\hline $\mathrm{T} 1,3,5$ & $\mathrm{~S}$ & $\mathrm{~S}$ & $\mathrm{R}$ & $\mathrm{S}$ & $\mathrm{R}$ & $\mathrm{S}$ & 3 \\
\hline $\mathrm{T} 1,2,3,4$ & $\mathrm{~S}$ & $\mathrm{~S}$ & $\mathrm{~S}$ & $\mathrm{~S}$ & $\mathrm{~S}$ & $\mathrm{R}$ & 17 \\
\hline $\mathrm{T} 1,2,3,5$ & $\mathrm{~S}$ & $\mathrm{~S}$ & $\mathrm{~S}$ & $\mathrm{~S}$ & $\mathrm{R}$ & $\mathrm{S}$ & 18 \\
\hline $\mathrm{T} 1,3,4,5$ & $\mathrm{~S}$ & $\mathrm{~S}$ & $\mathrm{R}$ & $\mathrm{S}$ & $\mathrm{S}$ & $\mathrm{S}$ & 1 \\
\hline $\mathrm{T} 1,2,3,4,5$ & $\mathrm{~S}$ & $\mathrm{~S}$ & $\mathrm{~S}$ & $\mathrm{~S}$ & $\mathrm{~S}$ & $\mathrm{~S}$ & 8 \\
\hline Total & $\ldots$ & $\ldots$ & $\ldots$ & $\ldots$ & $\ldots$ & $\ldots$ & 177 \\
\hline
\end{tabular}

${ }^{a}$ Genes $P h-4$ and $P h-5$ conditioning late blight resistance in accessions L3708 and LA1033, respectively, are not yet characterized. S indicates a susceptible reaction and $\mathrm{R}$ indicates a resistant reaction.

${ }^{\mathrm{b}}$ Race designation is derived from the resistance genes that are defeated by the isolate; for instance, race T1,2 overcomes the resistance of TS33 and WV700, which possess the $P h-1$ and $P h-2$ genes, respectively.

${ }^{c}$ CLN2037B is one of the Asian Vegetable Research and Development Center's inbred lines introgressed with the Ph-3 resistance gene from the L3708 accession. 
Reports on the host specificity of $P$. infestans populations on tomato and potato vary among different geographic regions. In some regions of the Netherlands (16) and North America $(21,27), P$. infestans populations that infected both tomato and potato could not be distinguished by the neutral genetic markers, such as RFLP fingerprinting, dilocus allozyme genotype, or mating type. In contrast, the same genetic markers have shown that distinct genotypes are associated with different hosts in northwestern Mexico (20), the Philippines (26), and one region of the Netherlands (16). In addition, Oyarzun (30) reported that the isolates collected from Ecuador were separated into the tomato population and the potato population with the distinct genotypes US-1 and EC1 , respectively. Oyarzun also indicated that the EC-1 genotype was introduced into Ecuador and replaced the US-1 on potato but not on tomato. Our results are similar, but the US-11 replaced the US-1 on both

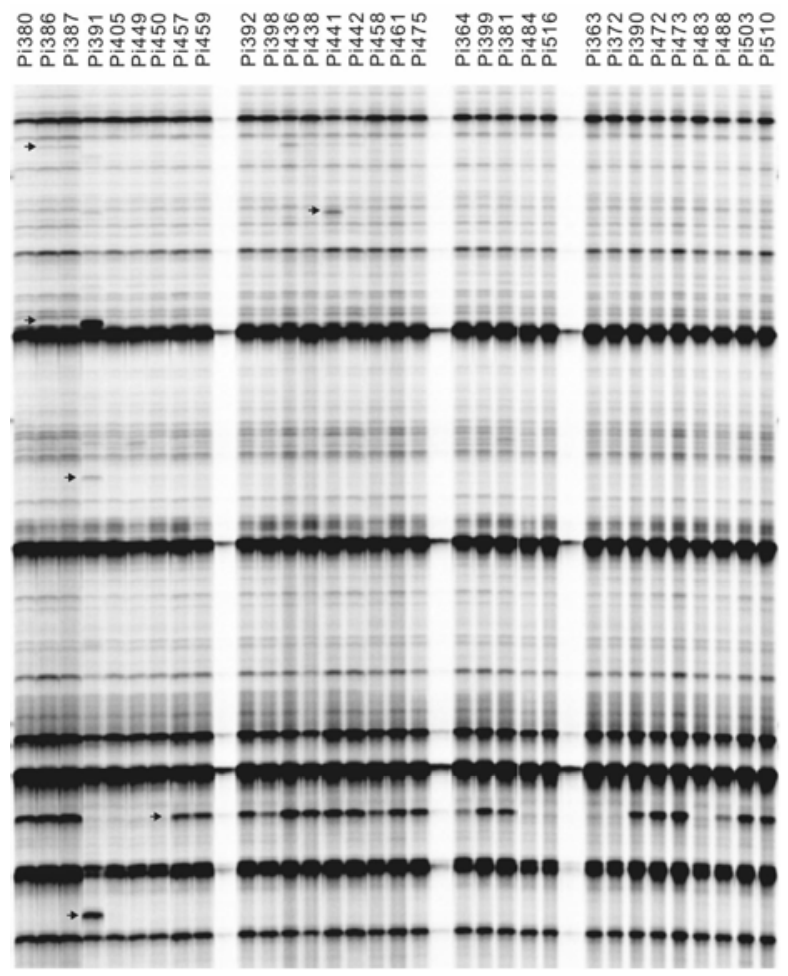

Fig. 2. Partial polyacrylamide gel of the amplified fragment length polymorphism markers of 32 Phytophthora infestans isolates with primer pair E-AA+M-ATAT. The isolates were selected from four tomato races (T1; T1,2; T1,3; and T1,2,3,5) of the population collected during 2004 and 2005. Some polymorphic bands are indicated with arrows.

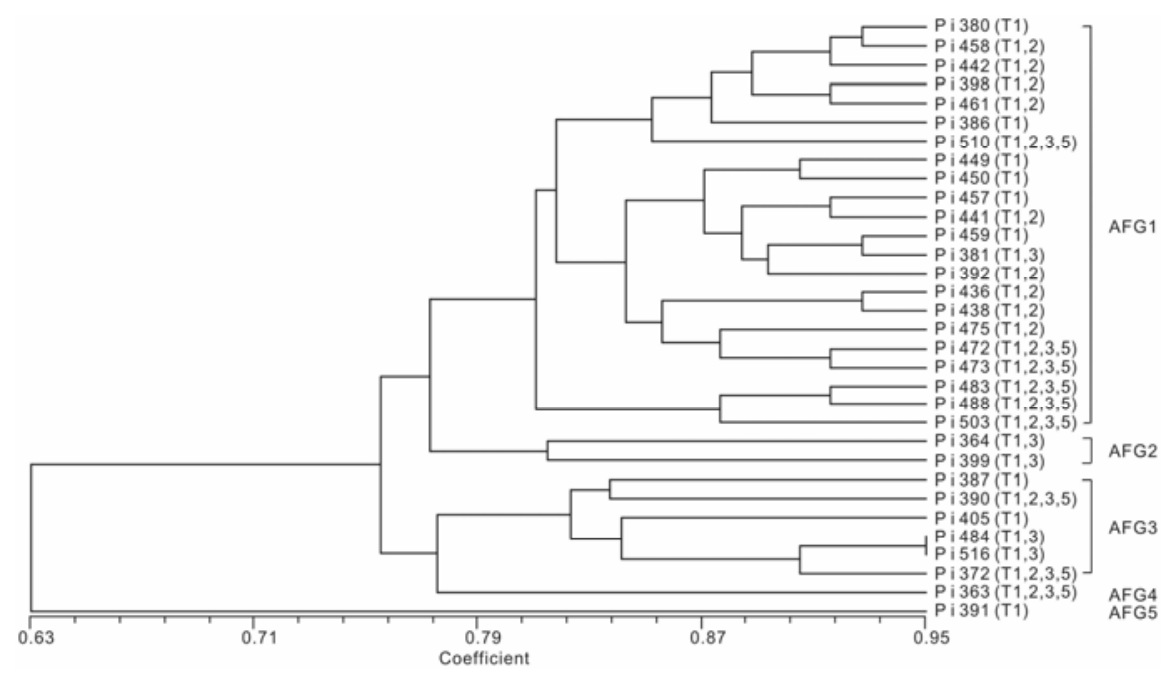

Fig. 3. Dendrogram of the 32 Phytophthora infestans isolates based on amplified fragment length polymorphism markers. Relative coefficient among these isolates was revealed by cluster analysis with the unweighted pair-group method and arithmetic averages. The scale shown below the dendrogram is the relative distance calculated using the simple matching coefficients.

potato and tomato. Oyarzun pointed out that no $P$. infestans isolates were found to be highly aggressive on both tomato and potato in the same geographic region (30); however, the current study has revealed that isolates collected from Taiwan are highly aggressive on both hosts. $P$. infestans could be particularly destructive where both tomato and potato are grown year round in the same geographic regions, as in the highland tropics of Africa, South America, and Asia.

Investigating race composition provides information that is especially important in breeding for crop resistance. Highly complex races of $P$. infestans on potato have been reported frequently $(11,15,23,30)$; however, only three race-specific resistance genes of tomato, $P h-1, P h-2$, and $P h$ 3 , have been reported previously $(10,29,31)$, where tomato lines possessing $P h-1$ and $P h-2$ were used as differentials to characterize the virulence phenotypes of $P$. infestans isolates on tomato $(11,30)$. The previous work at the AVRDC (7) has suggested that there are at least two additional race-specific genes, the putative $P h-4$ and $P h-5$ genes, in the set of tomato differentials used for the current study.

Based on our results, the tomato-related races are not specifically associated with sampled regions or the genotypes identified by neutral markers. No locationspecific races were found in this study. Furthermore, although the $P$. infestans isolates collected in this study all belonged to US-11 clonal linage, their diverse race composition is as complex as the multiple race composition reported on potato. The determinant of the specific virulence factors of $P$. infestans on tomato is unclear at this point, and it should be considered in future research.

The results of this study demonstrate high variability in race composition among the asexual population of $P$. infestans isolates in Taiwan during 2004 and 2005. The aggressive isolates appeared frequently and quickly even though no A2 mating type isolate has been detected in Taiwan thus far (data not show). This is the major difference of $P$. infestans in Taiwan compared with other regions worldwide. In general, detection of the more aggressive isolates of $P$. infestans has been associated with the appearance of the A2 mating type isolates $(17,26,34)$. Further studies to better understand the mechanisms of genetic variation are required.

Molecular markers such as random amplified polymorphic DNA (RAPD) and AFLP usually are used to assess total genetic variation, which is not directly affected by host or environmental factors that influence the expression of phenotypes (12). AFLP fingerprinting has been used to investigate the race-specific avirulence genes of $P$. infestans on potato $(22,36)$. Our results showed that the AFG1 AFLP group, which is composed of all 
four races, is the most predominant AFLP group (26/36) among the 32 isolates tested in this study. No race-specific marker of $P$. infestans on tomato was found by AFLP.

The lack of association between groups based on AFLP markers in this study was not unexpected; although it can reveal genetic variation in different regions of the genome. Our results agreed with the finding of Purvis et al. (32), who compared the AFLP markers with RG57-RFLP markers; they found isolates with dissimilar RG-57 markers but identical AFLP fingerprinting, whereas other isolates with the same RG57 fingerprinting were grouped into remarkably distinct AFLP genotypes. Abu-El Samen et al. (1) also reported that the $P$. infestans isolates derived from single zoospores of an individual isolate had multiple race compositions, AFLP markers, and RAPD fingerprints. The possible mechanisms of genotypic variability during asexual reproduction include mutation, mitotic crossing over, gene conversion, and extra chromosomal elements $(2,19)$. More than one mechanism might be involved in the phenotypic and genotypic diversity of $P$. infestans isolates. More genomic analysis will be conducted to screen for potential race-specific molecular markers.

\section{ACKNOWLEDGMENTS}

This project was funded, in part, by grant 94AS1.4-ID-01 from the Council of Agriculture, Taipei, Taiwan; and grant FG-TW-05 from the Research and Scientific Exchanges Division, International Cooperation and Development, United States Department of Agriculture. We thank C.-A. Liu (Biotech Unit, AVRDC) for providing supplies and equipment for our AFLP analysis.

\section{LITERATURE CITED}

1. Abu-El Samen, F. M., Secor, G. A., and Gudmestad, N. C. 2003. Genetic variation among asexual progeny of Phytophthora infestans detected with RAPD and AFLP markers. Plant Pathol. 52:314-325.

2. Abu-El Samen, F. M., Secor, G. A., Gudmestad, N. C. 2003. Variability in virulence among asexual progenies of Phytophthora infestans (Mont.) de Bary. Phytopathology 93:293-304.

3. Ann, P. J., and Chang, T. T. 2000. Why late blight of potato and tomato dramatically breaking out in Taiwan at the end of 1997. Pages 115-126 in: Proc. Information on Plants Pest, Disease and Control Strategies Workshop. C. W. Kao, K. C. Kuo, and J. C. Tseng, eds. Taiwan Agricultural Chemicals and Toxic Substances Research Institute, Wufeng, Taichung, Taiwan. (In Chinese with English abstract)

4. Ann, P. J., Chang, T. T., and Chern L. L. 1998. Mating type distribution and pathogenicity of Phytophthora infestans in Taiwan. Bot. Bull. Acad. Sin. 39:33-37.

5. Asian Vegetable Research and Development Center. 1998. Host resistance to late blight of tomato. Pages 83 in: AVRDC Report 1997. Asian Vegetable Research and Development Center, Shanhua, Tainan, Taiwan.
6. Asian Vegetable Research and Development Center. 2002. Tomato late blight studies. Pages 8-9 in: AVRDC Report 2001. Asian Vegetable Research and Development Center, Shanhua, Tainan, Taiwan.

7. Asian Vegetable Research and Development Center. 2003. Tomato late blight studies. Pages 12-14 in: AVRDC Report 2002. Asian Vegetable Research and Development Center, Shanhua, Tainan, Taiwan.

8. Black, L. L., Wang, T. C., Hanson, P. M., and Chen, J. T. 1996. Late blight resistance in four wild tomato accessions: effectiveness in diverse locations and inheritance of resistance. (Abstr.) Phytopathology 86:S24.

9. Caten, C. E., and Jinks, J. L. 1968. Spontaneous variability of single isolates of Phytophthora infestans. I. Cultural variation. Can. J. Bot. 46:329-348.

10. Chunwongse, J., Chunwongse, C., Black, L. L., and Hanson, P. 2002. Molecular mapping of the $P h-3$ gene for late blight resistance in tomato. J. Hortic. Sci. Biotechnol. 77:281-286.

11. Cohen, Y. 2002. Population of Phytophthora infestans in Israel under three major genetic changes during 1983 to 2000 . Phytopathology 92:300-307.

12. Cooke, D. E. L., and Lees, A. K. 2004. Markers, old and new, for examining Phytophthora infestans diversity. Plant Pathol. 53:692-704.

13. Deahl, K. L., Cooke, L. R., Black, L. L., Wang, T. C., Perez, F., Moravec, B. C., Quinn, M., and Jones, R. W. 2002. Population changes in Phytophthora infestans in Taiwan associated with the appearance of resistance to metalaxyl. Pest Manage. Sci. 58:951-958.

14. Deahl, K. L., DeMuth, S. P., Sinden, S. L., and Rivera-Pe a, A. 1995. Identification of mating types and metalaxyl resistance in North American populations of Phytophthora infestans. Am. Potato J. 68:717-725

15. Dorrance, A. E., Inglis, D. A., Derie, M. L., Brown, C. R., Goodwin, S. B., Fry, W. E., and Deahl, K. L. 1999. Characterization of Phytophthora infestans populations in Western Washington. Plant Dis. 83:423-428.

16. Fry, W. E., Drenth, A., Spielman, L. J., Mantel, B. C., Davidse, L. C., and Goodwin, S. B. 1991. Population genetic structure of Phytophthora infestans in the Netherlands. Phytopathology 81:1330-1336.

17. Fry, W. E., and Goodwin, S. B. 1997. Reemergence of potato and tomato late blight in the United States. Plant Dis. 81:1349-1357.

18. Fry, W. E., Goodwin, S. B., Dyer, A. T., Matuszak, J. M., Drenth, A., Tooley, P. W., Sujkowski, L. S., Koh, Y. J., Cohen, B. A., Spielman, L. J., Deahl, K. L., Inglis, D. A., and Sandlan, K. P. 1993. Historical and recent migrations of Phytophthora infestans, chronology, pathways, and implications. Plant Dis. 77:653-661.

19. Goodwin, S. B. 1997. The population genetics of Phytophthora. Phytopathology 87:462-473.

20. Goodwin, S. B., Spielman, L. J., Matuszak, J. M., Bergeron, S. N., and Fry, W. E. 1992. Clonal diversity and genetic differentiation of Phytophthora infestans populations in northern and central Mexico. Phytopathology 82:955961.

21. Goodwin, S. B., Sujkowski, L. S., Dyer, A. T., Fry, B. A., and Fry, W. E. 1995. Direct detection of gene flow and probable sexual reproduction of Phytophthora infestans in northern North America. Phytopathology 85:473-479.

22. Guo, J., Qu, D., Wang, X., Jin, L., Xie, K., Jiang, R. H. Y., and Govers, F. 2005. Identifica- tion of candidate expressed sequences associated with race-specific avirulence genes by cDNA-amplified fragment length polymorphism. Acta Hortic. Sin. 32:44-48. (In Chinese with English abstract)

23. Hermansen, A., Hannukkala, A., Nærstad, R. H., and Brurberg, M. B. 2000. Variation in population of Phytophthora infestans in Finland and Norway: mating type, metalaxyl resistance, and virulence phenotype. Plant Pathol. 49:11-12.

24. Jyan, M. H., Ann, P. J., Tsai, J. N., Hsih, S. D., Chang, T. T., and Liou, R. F. 2004. Recent occurrence of Phytophthora infestans US-11 as the cause of severe late blight on potato and tomato in Taiwan. Can. J. Plant Pathol. 26:188192.

25. Kim, M. J., and Mutschler M. A. 2005. Transfer to processing tomato and characterization of late blight resistance derived from Solanum pimpinellifolium L. L3708. J. Am. Soc. Hortic. Sci. 130:877-884

26. Koh, Y. J., Goodwin, S. B., Dyer, A. T., Cohen, B. A., Ogoshi, A., Sato, N., and Fry, W. E. 1994. Migrations and displacement of Phytophthora infestans populations in East Asian countries. Phytopathology 84:922-927.

27. Legard, D. E., Lee, T. Y., and Fry, W. E. 1995 Pathogenic specialization in Phytophthora infestans: Agressiveness on tomato. Phytopathology 85:1356-1361.

28. Lough, R. C. 2003. Inheritance of tomato late blight resistance in Lycopersicon hirsutum LA1033. Ph. D. thesis, Horticulture, North Carolina State University, Raleigh.

29. Moreau, P., Thoquet, P., Oliver, J., Laterrot, H., and Grimsley, N. 1998. Genetic mapping of $P h-2$, a single locus controlling partial resistance to Phytophthora infestans in tomato. Mol. Plant-Microbe Interact. 11:259-269.

30. Oyarzun, P. J., Pozo, A., Ordoñez, M. E., Doucett, K., and Forbes, G. A. 1998. Host specificity of Phytophthora infestans on tomato and potato in Ecuador. Phytopathology 88:265-271.

31. Peirce, L. C. 1971. Linkage tests with $P h$ conditioning resistance to race 0 , Phytophthora infestans. Tomato Genet. Coop. Rep. 21:30.

32. Purvis, A. I., Pipe, N. D., Day, J. P., Shattock, R. C., Shaw, D. S., and Assinder, S. J. 2001 AFLP and RFLP (RG57) fingerprints can give conflicting evidence about relatedness of isolates of Phytophthora infestans. Mycol. Res. 105:1321-1330.

33. Rohlf, F. J. 2000. NTSYS-pc: Numerical Taxonomy and Multivariate Analysis System, User Guider. Exeter Publishers, Setauket, NY.

34. Spielman, L. J., Drenth, A., Davidse, L. C., Sujkowski, L. J., Gu, W., Tooley, P. W., and Fry, W. E. 1991. A second worldwide migration and population displacement of Phytophthora infestans. Plant Pathol. 40:422430 .

35. van der Lee, T., De Witte, I., Drenth, A., Alfonso, C., and Govers, F. 1997. AFLP linkage map of the Oomycete Phytophthora infestans. Fungal Genet. Biol. 21:278-291.

36. van der Lee, T., Robold, A., Testa, A. Klooster, J. W., and Govers, F. 2001. Mapping of avirulence genes in Phytophthora infestans with amplified fragment length polymorphism markers selected by bulked segregant analysis. Genetics 157:949-956.

37. Vos, P., Hogers, R., Bleeker, M., Reijans, M., and van der Lee, T. 1995. AFLP: a new technique for DNA fingerprinting. Nucleic Acids Res. 23:4407-4414. 